\title{
Amblyomma cajennense infestation on horses in two microregions of the state of Rio de Janeiro, Brazil
}

Infestação por Amblyomma cajennense em equinos de duas microrregiôes do estado do Rio de Janeiro, Brasil

Marcus Sandes Pires ${ }^{1 *}$; Tiago Marques dos Santos²; Huarrisson Azevedo Santos ${ }^{3}$; Joice Aparecida Rezende Vilela ${ }^{1}$; Maristela Peckle Peixoto ${ }^{1}$; Erica Cristina Rocha Roier ${ }^{1}$; Claudia Bezerra da Silva ${ }^{1}$; Jairo Dias Barreira ${ }^{4}$; Elba Regina Sampaio de Lemos'; Carlos Luiz Massard ${ }^{1}$

${ }^{1}$ Departamento de Parasitologia Animal, Instituto de Veterinária, Universidade Federal Rural do Rio de Janeiro - UFRRJ, Seropédica, RJ, Brasil

${ }^{2}$ Departamento de Zootecnia, Instituto de Ciências Agrárias e Tecnológicas, Universidade Federal de Mato Grosso - UFMT, Cuiabá, MT, Brasil

${ }^{3}$ Departamento de Epidemiologia e Saúde Pública, Instituto de Veterinária, Universidade Federal Rural do Rio de Janeiro - UFRRJ, Seropédica, RJ, Brasil

${ }^{4}$ Departamento de Microbiologia e Parasitologia, Universidade Federal do Estado do Rio de Janeiro - UNIRIO, Rio de Janeiro, RJ, Brasil ${ }^{5}$ Laboratório de Hantaviroses e Rickettsioses, Instituto Osvaldo Cruz - FIOCRUZ, Rio de Janeiro, RJ, Brasil

Received July 27, 2012

Accepted December 18, 2012

\begin{abstract}
The objective of this study was to evaluate factors associated with infestation by Amblyomma cajennense on horses in two microregions of the state of Rio de Janeiro. Horses on 62 farms in the municipalities of the Itaguaí and Serrana microregions were evaluated between January and May 2009. The animals were examined to determine the presence of ticks and infestation level. The animals' rearing and management were assessed on each farm property using an epidemiological questionnaire. Out of the 635 horses evaluated, $41.6 \%$ were infested with $A$. cajennense. It was observed that farms in low-altitude regions $(\mathrm{OR}=3.69$; $\mathrm{CI}$ : 2.3-5.8), with unsatisfactory zootechnical and sanitary management (OR=5.92; CI: 3.8-9.2) and an extensive rearing system (OR=4.25; CI: 2.1-8.5) were factors associated with tick infestation $(\mathrm{p}<0.05)$ and also with cases of high infestation on horses. Use of chemical acaricides on horses was also associated with infestation $(p<0.05)$; the owners described different therapeutic approaches with different treatment intervals. From the present study, low altitudes, unsatisfactory management, extensive rearing and inappropriate use of acaricide products were factors associated with occurrences of $A$. cajennense at different infestation levels on horses in these municipalities.
\end{abstract}

Keywords: Ticks, associated factors, equines, infestation, Rio de Janeiro.

\section{Resumo}

O objetivo deste estudo foi avaliar os fatores associados à infestação por Amblyomma cajennense em equinos em duas microrregiôes do estado do Rio de Janeiro. Equinos de 62 fazendas nos municípios das microrregiốes de Itaguaí e Serrana foram avaliados entre janeiro e maio de 2009. Os animais foram inspecionados quanto à presença e ao nível de infestaçáo destes carrapatos. As condiçóes de criaçáo e o manejo foram avaliados em cada propriedade, por um questionário epidemiológico. Dos 635 equinos avaliados, $41,6 \%$ apresentavam-se infestados por $A$. cajennense. Observou-se que as criaçóes dos animais em regiôes de baixas altitudes ( $\mathrm{OR}=3,69$, IC: 2,3-5,8), em propriedades com manejo zootécnico e sanitário insatisfatório $(\mathrm{OR}=5,92$, IC: 3,8-9,2) e em sistema de criação extensivo $(\mathrm{OR}=4,25$, IC: $2,1-8,5)$ foram fatores associados $(\mathrm{p}<0,05)$ à infestação, sendo também relacionados à intensa infestação nos equinos. $\mathrm{O}$ uso de carrapaticida nos equinos também apresentou associação $(\mathrm{p}<0,05)$ à infestação, sendo descritas pelos proprietários, diferentes condutas terapêuticas, em intervalos alternados de tratamento. Baixas altitudes, condição de manejo insatisfatória, criação extensiva e o uso inadequado dos produtos carrapaticidas sáo fatores associados à ocorrência de $A$. cajennense em diferentes níveis de infestação nos equinos dos municípios estudados.

Palavras-chave: Carrapatos, fatores associados, equinos, infestação, Rio de Janeiro.

\footnotetext{
${ }^{*}$ Corresponding author: Marcus Sandes Pires

Departamento de Parasitologia Animal, Universidade Federal Rural do

Rio de Janeiro - UFRRJ, BR 465, Km 7, Seropédica, CEP 23890-000,

Rio de Janeiro, RJ, Brasil.

e-mail: marcussandes@yahoo.com.br
} 


\section{Introduction}

Amblyomma cajennense (Fabricius, 1787), commonly known as "Cayenne tick", is widely dispersed in the Americas, from the southern United States to Argentina (COOLEY; KOHLS, 1944). In Brazil, it is distributed throughout the national territory (LABRUNA et al., 2004; ESTRADA-PENA et al., 2004), although it is found mostly in the southeast (VIEIRA et al., 2002). This ectoparasite causes economic losses among livestock due to reduction of the animals' productivity (OLIVEIRA, 2004; CUNHA et al., 2007) and the high cost of using acaricides (PRATA et al., 1996). Because of this arthropod's low parasitic specificity, it may infest many species of wild and domestic animals, including humans (ARAGÃO; FONSECA, 1961; PAROLA; RAOULT, 2001), although horses are the preferred hosts (LABRUNA et al., 2002; LOPES et al., 1998).

In addition to spoliation on the host's skin, this species is known as a transmitter of some pathogens to animals (MASSARD, 1984) and humans (GUGLIELMONE et al., 2006). Among these pathogens is the bacterium Rickettsia rickettsii, the etiological agent of Brazilian spotted fever, an important public health problem in different regions of Brazilian territory (DIAS; MARTINS, 1939; LEMOS et al., 1997; ROZENTAL et al., 2002; GUEDES et al., 2005). In the state of Rio de Janeiro, from 2004 to 2008, there were 28 confirmed cases of Brazilian spotted fever (MOLITERNO, 2009). When Labruna et al. (2001) assessed factors associated with infestation by $A$. cajennense in horse rearing, it was observed that animals that grazed on mixed overgrowth pasture, composed of numerous shrubs and herbs, were more favored for tick infestation. Moreover, many breeders use acaricide treatments at volumes lower than the recommended levels for horses (LABRUNA, 2000), which favors maintenance of the tick population in the environment. Accordingly, knowledge of the epidemiological factors that may influence the presence of $A$. cajennense on horses is fundamental for developing more effective control strategies against this ectoparasite. The objective of this study was to evaluate factors associated with $A$. cajennense tick infestation on horses in two microregions of the state of Rio de Janeiro.

\section{Materials and Methods}

Sampling - A total of 62 farms that kept horses were evaluated in two municipalities of the Serrana microregion (Petrópolis and Teresópolis) and three municipalities of the Itaguaí microregion (Mangaratiba, Itaguaí and Seropédica), in the state of Rio de Janeiro, between January and May 2009. A convenience sampling was used in both microregions selected. The minimum number of samples to be collected was 267 horses per microregion, according to the equation described by Sampaio (2002), considering a confidence interval of $95 \%$ and error margin of $6 \%$, and assuming an expected prevalence of 50\%. However, 297 horses were analyzed in the Serrana microregion (Petrópolis, $\mathrm{n}=134$; and Teresópolis, $\mathrm{n}=163$ ) and 338 horses in the Itaguaí microregion (Mangaratiba, $\mathrm{n}=84$; Itaguaí, $\mathrm{n}=116$; and Seropédica, $\mathrm{n}=138$ ), thus totaling 635 animals analyzed. After obtaining the owners' consent, the animals were examined to determine the presence of Amblyomma ticks and the infestation level. From each horse that was infested with ticks, some adult tick specimens that were visually identified as belonging to the genus Amblyomma were collected. These were stored in isopropyl alcohol and sent to the Hemoparasites and Vectors Laboratory of the Federal Rural University of Rio de Janeiro, for identification at species level using an appropriate dichotomous key (BARROS-BATTESTI et al., 2006). The A. cajennense infestation level was categorized based on adult species observed on the animals, at four frequency levels: none, few, moderate and many, as described by Teglas et al. (2005).

Epidemiological questionnaire - A semi-structured questionnaire was applied to the owners in order to identify possible factors associated with $A$. cajennense infestation on horses. Data on the characteristics of each farm, management condition and details relating to each horse and the $A$. cajennense infestation level were then gathered. The survey questions were organized as follows: Itaguaí microregion (low-altitude region, of less than 400 meters in elevation) and Serrana microregion (high-altitude region, of more than 400 meters in elevation); satisfactory zootechnical and sanitary management (appropriate zootechnical buildings for the horses, adequate food for the animals, farm with adequate infrastructure, presence of sanitary control and constant veterinary assistance) and unsatisfactory zootechnical and sanitary management (inappropriate zootechnical buildings, farm with inadequate infrastructure, absence of a balanced diet, routine lacking systematic sanitary control and when veterinary assistance was present, it was sporadic or used only in cases of emergency); confined/semi-confined rearing system (horses did not have or only partially had access to pasture) and extensive rearing system (horses only had access to pasture); close contact with cattle (cattle and horses shared the same pasture or were near to each other) and without contact with cattle; gender (male or female); age (under two years old or older than two years); and breed definition (purebred horses or mixed-breed horses). The acaricide treatment used on each farm was also evaluated, according to its type, periodicity and chemical basis. The elevation of each farm was measured using the global positioning system (GPS).

Statistical analysis - To evaluate the factors associated with A. cajennense tick infestation on horses, a multivariate model was used through multiple logistic regression, correlating the dependent variable at dichotomous qualitative levels (no ticks $=0$; presence of ticks $=1$ ) with the abovementioned independent variables, also at dichotomous levels for each category evaluated. Initially, the dependent variable was analyzed for the presence of a statistical association at the significance level of $\mathrm{p}<0.20$ (chi-square test) according to the independent variables, and then tested in the multivariate model (LABRUNA et al., 2001). The tick infestation level variable was re-categorized from four infestation levels (none, few, moderate or many) into dichotomous qualitative levels (none or few $=0$; moderate or many $=1$ ), selecting those with a statistical association at the significance level of $\mathrm{p}<0.20$ (chi-square test) for multivariate analysis, through the multiple logistic regression model.

To evaluate the association between use of chemical acaricides and the presence of horses that were infested with $A$. cajennsense, the chi-square test or Fisher's exact test was performed at the 
5\% significance level. All analyses were performed using the $\mathrm{R}$ statistical software, version 2.11.1 (R DEVELOPMENT CORE TEAM, 2010).

This project was approved by the Research Ethics Committee of the Federal Rural University of Rio de Janeiro, under procedural number 23083.005971/2011-30 (Protocol No. 127/2011).

\section{Results}

All the ticks collected from the horses were identified as A. cajennense (Fabricius, 1787) (Acari: Ixodidae). The characteristics of the farms and horses infested with $A$. cajennense in the two microregions are presented in Table 1 . The mean \pm standard deviation of the examined animals per farm was $10.2 \pm 8.1$ (range: $1-40$ ) and the mean \pm standard deviation of the infested animals per farm was $4.3 \pm 6.1$ (range: 0 -37) (Table 1 ). The highest frequency of farm properties with infested horses was observed in the Itaguaí microregion $(96.7 \% ; \mathrm{n}=30)$ (Table 1). The mean number \pm standard deviation of farm elevation $(\mathrm{m})$ in the low-altitude region (Itaguaí microregion) and high-altitude region (Serrana microregion) were respectively $22.8 \pm 17.1 \mathrm{~m}$ (range: $1-81)$ and $805.2 \pm 91.2 \mathrm{~m}$ (range: $470-1004)$.

Out of all the horses examinated, $264(41.6 \% ; \mathrm{n}=635)$ were infested by $A$. cajennense, according to the visual inspection. The highest frequency of infested horses was observed in the municipality of Seropédica $(79.7 \%$; $n=138)$, followed by Itaguaí $(58.6 \%$; $\mathrm{n}=116)$. Both of the municipalities in the Serrana microregion (high-altitude region) had low frequencies of infestation on the animals, and Petrópolis had the lowest frequency observed (13.4\%; $\mathrm{n}=134$ ). In relation to the infestation level, it was observed that the two microregions had horses with different levels of $A$. cajennense infestation. The Itaguaí microregion presented a higher percentage of horses with high infestation, comprising $10.9 \%$ of the animals $(\mathrm{n}=338)$ (Figure 1).

Table 2 shows the bivariate and multivariate analysis on factors associated with $A$. cajennense parasitism. Statistical associations were found with all the independent variables in the bivariate analysis, except for age ( $p>0.20 ; \chi 2: 0.15)$ and breed definition ( $\left.p>0.20 ; \chi^{2}: 0.10\right)$ (Table 2 ). It is noteworthy that among the results from bivariate analysis, it was found that the majority of the horses infested with $A$. cajennense were male, in low-altitude regions (Itaguaí microregion), on farms with unsatisfactory zootechnical and sanitary management and an extensive rearing system, with cattle and horses sharing the same pasture or kept near to each other $(\mathrm{p}<0.20)$. When these variables were subjected to logistic regression, only the region, management and rearing system were associated with $A$. cajennense parasitism $(\mathrm{p}<0.05)$ (Table 2). Among these factors, unsatisfactory zootechnical and sanitary management had the highest association $(\mathrm{OR}=5.92$; $\mathrm{CI}$ : 3.8-9.2), followed by extensive rearing system $(\mathrm{OR}=4.25$; $\mathrm{CI}$ : 2.1-8.5) and low-altitude region ( $\mathrm{OR}=3.69$; CI: 2.3-5.8).

Table 3 shows an analysis on the independent variables among horses that were highly infested with $A$. cajennense. When the infestation level was evaluated using dichotomous categories, both in bivariate analysis and in multivariate analysis, high ticks infestation on horses showed strong associations with unsatisfactory zootechnical and sanitary management $(\mathrm{p}<0.05$; OR=7.27; CI: 3.6-14.6), low-altitude regions $(\mathrm{OR}=3.62$; $\mathrm{CI}: 1.8-7.2)$ and use of an extensive rearing system for these animals $(\mathrm{p}<0.05$; $\mathrm{OR}=2.50$; CI: $1.3-4.5)$.

The frequencies of farms and horses with $A$. cajennense parasitism relating to management practices involving the use of chemical acaricide products are presented in Table 4. The use of chemical acaricide products was statistically associated with $A$. cajennense parasitism on horses $(\mathrm{p}<0.05)$. Among all the farms analyzed that used chemical acaricide products, $84.6 \%(n=52)$ had at least one horse that was infested with $A$. cajennense. Likewise, the frequency of treated horses that were infested was $49.0 \%$ ( $n=261 / 533$ ), which differed significantly from the frequency of untreated horses (only $2.9 \% ; n=3 / 102$ ). In relation to the interval between insecticide treatments, it was observed that treatment done weekly or monthly showed higher frequencies of infestation, in comparison with horses that were treated randomly.

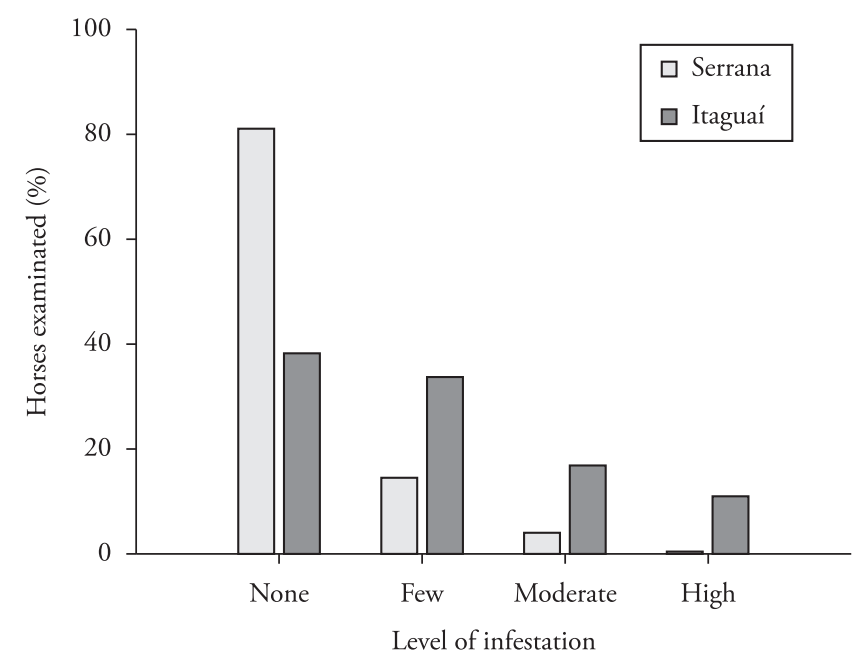

Figure 1. Level of $A$. cajennense infestation among horses in two microregions of the state of Rio de Janeiro, 2009.

Table 1. Characteristics of farm properties and horses infested by Amblyomma cajennense in two microregions of the state of Rio de Janeiro, 2009.

\begin{tabular}{|c|c|c|c|c|c|c|c|c|c|c|}
\hline \multirow[t]{2}{*}{ Microregions } & \multirow{2}{*}{$\begin{array}{c}\begin{array}{c}\text { Number of } \\
\text { farms* }\end{array} \\
\mathbf{N}\end{array}$} & \multirow{2}{*}{$\begin{array}{c}\text { Proportion of farms with } \\
\text { infested horses* }\end{array}$} & \multicolumn{4}{|c|}{ Horses per farm } & \multicolumn{4}{|c|}{ Infested horses per farm } \\
\hline & & & $\mathbf{M}$ & SD & SE & Range & $\mathbf{M}$ & SD & SE & Range \\
\hline Serrana & 32 & 50.0 & 9.3 & 6.1 & 1.1 & $(1-22)$ & 1.6 & 2.9 & 0.5 & $(0-14)$ \\
\hline Itaguaí & 30 & 96.7 & 11.3 & 9.8 & 1.8 & $(1-40)$ & 7.1 & 7.4 & 1.3 & $(0-37)$ \\
\hline Total & 62 & 72.6 & 10.2 & 8.1 & 1.0 & $(1-40)$ & 4.3 & 6.1 & 0.8 & $(0-37)$ \\
\hline
\end{tabular}

N: Total number sampled; M.: Mean; SD: Standard deviation; SE: Standard Error; \%: percentage; *All farm properties evaluated. 
Table 2. Bivariate and multivariate analyses on factors associated with infestation by Amblyomma cajennense among horses, according to gender, age, breed definition and management of the animals on farm properties in two microregions of the state of Rio de Janeiro, 2009.

\begin{tabular}{|c|c|c|c|c|c|c|c|}
\hline \multirow{2}{*}{$\begin{array}{l}\text { Characteristics of the } \\
\text { animals and their management }\end{array}$} & \multirow{2}{*}{$\mathbf{N}$} & \multirow{2}{*}{$(\%)$} & \multicolumn{2}{|c|}{ Bivariate } & \multicolumn{3}{|c|}{ Multivariate } \\
\hline & & & $\chi^{2}$ & $\mathbf{P}$ & $\mathbf{P}$ & OR & $95 \% \mathrm{CI}$ \\
\hline \multicolumn{8}{|l|}{ Gender } \\
\hline Female & 285 & 37.5 & \multirow{2}{*}{3.45} & \multirow{2}{*}{0.07} & \multirow{2}{*}{0.28} & - & - \\
\hline Male & 350 & 44.9 & & & & - & - \\
\hline \multicolumn{8}{|l|}{ Age } \\
\hline$<2$ years & 71 & 39.4 & \multirow{2}{*}{0.15} & \multirow{2}{*}{0.79} & \multirow{2}{*}{-} & - & - \\
\hline$\geq 2$ years & 564 & 41.8 & & & & - & - \\
\hline \multicolumn{8}{|l|}{ Breed definition } \\
\hline Purebred & 303 & 40.9 & \multirow{2}{*}{0.10} & \multirow{2}{*}{0.81} & \multirow{2}{*}{-} & - & - \\
\hline Mixed breed & 332 & 42.2 & & & & - & - \\
\hline \multicolumn{8}{|l|}{ Microregion } \\
\hline Serrana (high altitude) & 297 & 17.5 & \multirow{2}{*}{133.04} & \multirow{2}{*}{0.00} & \multirow{2}{*}{0.00} & * & - \\
\hline Itaguaí (low altitude) & 338 & 62.7 & & & & 3.69 & $(2.3-5.8)$ \\
\hline \multicolumn{8}{|l|}{$\begin{array}{l}\text { Zootechnical and } \\
\text { sanitary management }\end{array}$} \\
\hline Satisfactory & 365 & 17.0 & \multirow{2}{*}{213.66} & \multirow{2}{*}{0.00} & \multirow{2}{*}{0.00} & $*$ & - \\
\hline Unsatisfactory & 270 & 74.8 & & & & 5.92 & $(3.8-9.2)$ \\
\hline \multicolumn{8}{|l|}{ Rearing system } \\
\hline Semi-confined/confined & 520 & 31.5 & \multirow{2}{*}{119.06} & \multirow{2}{*}{0.00} & \multirow{2}{*}{0.00} & * & - \\
\hline Extensive & 115 & 87.0 & & & & 4.25 & $(2.1-8.5)$ \\
\hline \multicolumn{8}{|l|}{ Contact with cattle } \\
\hline No & 494 & 32.4 & \multirow{2}{*}{77.28} & \multirow{2}{*}{0.00} & \multirow{2}{*}{0.32} & - & - \\
\hline Yes & 141 & 73.8 & & & & - & - \\
\hline
\end{tabular}

N: Number of animals sampled; $\chi^{2}$ : value of chi-square test; P: p-value; OR: odds ratio; CI: confidence interval; \%: percentage; ${ }^{*}$ category reference.

Table 3. Bivariate and multivariate analyses on factors associated with high infestation by Amblyomma cajennense among horses, according to gender, age, breed definition and management of the animals on farm properties in two microregions of the state of Rio de Janeiro, 2009.

\begin{tabular}{|c|c|c|c|c|c|c|c|}
\hline \multirow{2}{*}{$\begin{array}{l}\text { Characteristics of the } \\
\text { animals and their management }\end{array}$} & \multirow{2}{*}{$\mathbf{N}$} & \multirow{2}{*}{$(\%)$} & \multicolumn{2}{|c|}{ Bivariate } & \multicolumn{3}{|c|}{ Multivariate } \\
\hline & & & $\chi^{2}$ & $\mathbf{P}$ & $\mathbf{P}$ & OR & $95 \% \mathrm{CI}$ \\
\hline \multicolumn{8}{|l|}{ Gender } \\
\hline Female & 285 & 16.8 & \multirow{2}{*}{0.08} & \multirow{2}{*}{0.98} & \multirow{2}{*}{-} & - & - \\
\hline Male & 350 & 16.6 & & & & - & - \\
\hline \multicolumn{8}{|l|}{ Age } \\
\hline$<2$ years & 71 & 18.3 & \multirow{2}{*}{0.15} & \multirow{2}{*}{0.82} & \multirow{2}{*}{-} & - & - \\
\hline$\geq 2$ years & 564 & 16.5 & & & & - & - \\
\hline \multicolumn{8}{|l|}{ Breed definition } \\
\hline Purebred & 303 & 17.8 & \multirow{2}{*}{0.53} & \multirow{2}{*}{0.53} & \multirow{2}{*}{-} & - & - \\
\hline Mixed breed & 332 & 15.7 & & & & - & - \\
\hline \multicolumn{8}{|l|}{ Microregion } \\
\hline Serrana (high altitude) & 297 & 4.4 & \multirow{2}{*}{60.86} & \multirow{2}{*}{0.00} & \multirow{2}{*}{0.00} & $*$ & - \\
\hline Itaguaí (low altitude) & 338 & 27.5 & & & & 3.62 & $(1.8-7.2)$ \\
\hline \multicolumn{8}{|l|}{$\begin{array}{l}\text { Zootechnical and } \\
\text { sanitary management }\end{array}$} \\
\hline Satisfactory & 365 & 3.3 & \multirow{2}{*}{110.92} & \multirow{2}{*}{0.00} & \multirow{2}{*}{0.00} & * & - \\
\hline Unsatisfactory & 270 & 34.8 & & & & 7.27 & $(3.6-14.6)$ \\
\hline \multicolumn{8}{|l|}{ Rearing system } \\
\hline Semi-confined/confined & 520 & 10.8 & \multirow{2}{*}{72.45} & \multirow{2}{*}{0.00} & \multirow{2}{*}{0.00} & $*$ & - \\
\hline Extensive & 115 & 43.5 & & & & 2.50 & $(1.3-4.5)$ \\
\hline \multicolumn{8}{|l|}{ Contact with cattle } \\
\hline No & 494 & 12.6 & \multirow{2}{*}{27.45} & \multirow{2}{*}{0.00} & \multirow{2}{*}{0.26} & - & - \\
\hline Yes & 141 & 31.2 & & & & - & - \\
\hline
\end{tabular}

N: Number of animals sampled; $\chi^{2}$ : value of chi-square test; P: p-value; OR: odds ratio; CI: confidence interval; \%: percentage; ${ }^{*}$ category reference. 
Table 4. Frequencies of farm properties and horses infested by Amblyomma cajennense according to acaricide treatment, application interval and chemical basis used in two microregions of the state of Rio de Janeiro, 2009.

\begin{tabular}{|c|c|c|c|c|}
\hline \multirow[t]{2}{*}{ Acaricide treatment } & \multicolumn{2}{|c|}{ Infested horses per farm } & \multicolumn{2}{|c|}{ Horses infested } \\
\hline & $\mathbf{N}$ & $(\%)$ & $\mathbf{N}$ & $(\%)$ \\
\hline \multicolumn{5}{|l|}{ Use of acaricide ${ }^{* *}$} \\
\hline Yes & 52 & 84.6 & 533 & $49.0^{\mathrm{a}}$ \\
\hline No & 10 & 10.0 & 102 & $2.9^{\mathrm{b}}$ \\
\hline \multicolumn{5}{|l|}{ Periodicity of treatment } \\
\hline Once to twice per month & 12 & 100.0 & 113 & 55.8 \\
\hline Three to four times per month & 8 & 100.0 & 45 & 71.1 \\
\hline Twice to six times per year & 6 & 100.0 & 77 & 85.7 \\
\hline Randomly/when infested animals seen & 17 & 64.7 & 233 & 27.0 \\
\hline No answer* & 9 & 77.8 & 65 & 56.9 \\
\hline \multicolumn{5}{|l|}{ Chemical basis used } \\
\hline Organophosphate & 5 & 80.0 & 28 & 21.4 \\
\hline Pyrethroid & 15 & 80.0 & 134 & 47.0 \\
\hline Organophosphate/pyrethroid & 7 & 71.4 & 84 & 39.3 \\
\hline Organophosphate/pyrethroid/others & 5 & 80.0 & 36 & 80.6 \\
\hline Others & 5 & 80.0 & 58 & 39.7 \\
\hline No answer* & 15 & 100.0 & 193 & 55.4 \\
\hline
\end{tabular}

${ }^{2}$ Values followed by the same letters, in the same column, do not differ statistically according to the chi-square test or Fisher's exact test, at $5 \%$ significance level. $\mathrm{N}$ : Total number sampled; \%: percentage; ${ }^{*}$ Respondents who did not give any answer. ${ }^{*}$ Statistical analysis only on this topic.

Organophosphates, pyrethroids or associations between these two bases were mentioned as chemical controls for $A$. cajennense in at least 32 farms $(51.6 \% ; n=62)$. Other acaricide bases such as phenylpyrazole and an association of citronella, pyrethroid and organophosphates were also cited as treatments for the animals, but these were less significant than the others. It was observed that horses treated with pyrethroid showed higher frequencies of this tick infestation $(47.0 \% ; \mathrm{n}=134)$ than did those treated with the combination of organophosphates and pyrethroid $(39.3 \%$; $\mathrm{n}=84)$ or with organophosphates separately $(21.4 \% ; \mathrm{n}=28)$.

It is noteworthy that many owners did not answer the questions regarding frequency of application $(14.5 \% ; n=62)$ and the chemical basis used $(24.2 \% ; \mathrm{n}=62)$. Nonetheless, it was observed that, at least 14 farms $(22.6 \% ; n=62)$ had used a spraying method on their horses, with lower volumes of acaricide emulsion than the manufacturers recommended.

\section{Discussion}

The distribution and occurrence of $A$. cajennense on horses in Brazil have been studied in some regions (SOUZA; SERRAFREIRE, 1994; LEMOS et al., 1997; HEUCHERT et al., 1999; LABRUNA et al., 2001, 2002; OLIVEIRA et al., 2003; ESTRADA-PEÑA et al., 2004). In the present study, in the microregions evaluated, high frequency of infested horses was observed, mostly with adult ticks. The occurrence and infestation levels varied among the horses. Horses are considered to be this tick's primary host (LABRUNA et al., 2001). The seasonality of $A$. cajennense in the southeastern states of Brazil is associated with climatic factors, and population dynamics vary according to the developmental stages of the tick. Thus, the larval and nymph stages are mostly present in the autumn and winter, while the adult stage is observed mostly during the spring and summer (SERRAFREIRE, 1982; LEMOS et al., 1997; OLIVEIRA et al., 2000; LABRUNA et al., 2002). Oliveira et al. (2003) observed that the adult stage of $A$. cajennense was found more often on horses during January to March, in Minas Gerais. Souza and Serra-Freire (1992) observed intense parasitism by adults of $A$. cajennense on horses in the municipality of Seropédica, between October and May.

Throughout this study, it was observed that the most infested horses belonged to farms in lowland regions. Accordingly, it can be suggested that this tick infestation is closely related to environmental and climatic conditions, which probably support the development of this arthropod better in low-altitude regions. Besides these factors, it was also noted that a large number of owners practiced unsatisfactory zootechnical and sanitary management, which certainly promoted the common occurrences of $A$. cajennense on animals in the study area.

The farms in the Serrana microregion are located at high altitudes, with a humid subtropical climate, consisting of wet summers and dry winters, with an average annual temperature of around $18^{\circ} \mathrm{C}$. Therefore, the low frequency of infested horses in this region may be associated with the deleterious effects of the weather conditions on this tick's biology. According to Estrada-Peña et al. (2004), the records of $A$. cajennense in Brazil are mostly from areas with average annual temperatures of $20{ }^{\circ} \mathrm{C}$ ( range $\left.=18-26^{\circ} \mathrm{C}\right)$. Although $A$. cajennense is widely distributed in Brazil, lower temperatures are probably what prevent its establishment in the southern region of the country (LABRUNA et al., 2001). The results obtained from the present study corroborate the findings of Chacón et al. (2003), who observed under laboratory conditions that $3.0 \%$ of the larvae hatched and $77.2 \%$ of the eggs curled when the tick eggs were maintained at $18{ }^{\circ} \mathrm{C}$, thus showing the deleterious effect of low temperature on this tick species. These 
same authors also analyzed larval development at a temperature of $27^{\circ} \mathrm{C}$ and observed that $54.6 \%$ of the larvae hatched. Therefore, the Itaguaí microregion's average annual temperature of around $27^{\circ} \mathrm{C}$ presents more favorable conditions for development of this tick (DAEMON; ISHIZUKA, 1992).

Climatic characteristics, factors relating to horse rearing, farm conditions, hygiene practices and acaricide treatments are important parameters for evaluating the factors possibly associated with the presence of this arthropod and its proliferation at breeding sites. In the present study, in addition to environmental factors, management conditions also showed a direct association with the presence and level of $A$. cajennense infestation on horses. This result was reinforced by the occurrence of high levels of infestation on some horses on farms where the weather conditions were less favorable to ticks (high altitude and lower temperature). Furthermore, there were cases of absence of tick infestation on horses in low-altitude regions (higher temperatures), where, theoretically, there are better conditions for arthropod development. These findings are probably related to better zootechnical and sanitary management of horse rearing.

The association between the extensive rearing system and tick infestation on horses emphasizes the idea that animals that remain in contact with pasture for longer times are at higher risk of infestation. The seasonal dynamics of $A$. cajennense in different pasture areas in the state of Rio de Janeiro have been well discussed in other studies, with emphasis on the presence of different tick stages over the course of the year (SERRA-FREIRE, 1982; SOUZA; SERRA-FREIRE, 1992). In the present study, it was observed that animals from farms using an extensive rearing system were more likely to have high infestation, due to the high frequency observed on these horses, in comparison with horses on farms with intensive or semi-intensive rearing systems. Labruna et al. (2001) observed that horses that had access to mixed overgrowth pasture, composed of numerous shrubs and herbs interposed with grasses, presented a 13-fold greater chance of infestation by A. cajennense. This pasture condition was associated with farms that did not mow all the pastures at least once a year. During the present study, the pasture characteristics on the farm properties analyzed were not checked rigorously. However, it was observed subjectively that many animals reared only on pasture belonged to farms with unsatisfactory management conditions, which often did not mow the pasture periodically and did not possess adequate machinery for this, such as mechanical mowing machines. The absence of regular mowing of the pasture may have favored establishment of tick populations in these areas.

Once infested, the horses participate directly in the dispersal of $A$. cajennense over the entire pasture area, thus scattering the arthropod population across the environment and increasing the tick infestation on the animals. This genus of tick has low host specificity and may parasitize other animals like birds, capybaras, dogs, raccoons, coatis, rats (PEREZ et al., 2008) and cattle (SERRA-FREIRE; CUNHA, 1987). Furthermore, tick infestation may be observed at different levels of parasitism, which expands its ability to spread across the environment. In the current study, it was observed that horses near to or in the same pastures as cattle were more frequently infested by $A$. cajennense. Although some studies have shown that having horses and cattle in the same pasture favors infestation of horses by Rhipicephalus (Boophilus) microplus (Canestrini, 1887) (HEUCHERT et al., 1999; LABRUNA et al., 2001), A. cajennense may also develop on cattle (SERRA-FREIRE; CUNHA, 1987) and thus, this could increase the infestation rate in pasture areas.

The chemical acaricide treatments used by the owners of several farms were reported as being used in different therapeutic ways. However, it is important to note that the pyrethroid group is the only one suitable for baths on horses, due to its efficiency and safety for horses and owners. Moreover, pyrethroids are available on the Brazilian market for controlling $A$. cajennense (PINHEIRO, 1987; BITTENCOURT et al., 1989). According to these authors, this tick requires higher concentrations of acaricide than those used to control $R$. (B). microplus. Some owners have reported using organophosphates. In Brazil, $A$. cajennense has been controlled empirically, using chemical acaricides based on organophosphates, carbamates, amidines and synthetic pyrethroids at the concentrations recommended for controlling the cattle tick, R. (B). microplus (PINHEIRO, 1987).

Even though use of organophosphate-based treatments was not recommended for controlling $A$. cajennense, this practice occurs and may be associated with the presence of simultaneous infestations by other tick species such as Dermacentor (Anocentor) nitens (Neumann, 1897), since the presence of this tick species on horses was often observed during the present study. Thus, animals that present mixed infestation of ticks or a high level of infestation probably retain more attention from their owners, since the high infestation level allows it to be clearly seen, which justifies the treatment. However, it is noteworthy that some horses that were treated only with pyrethroids were also infested with $A$. cajennense at different intensity levels. The tick infestation in the present study, even when chemical acaricide products were used, may be related to the absence of a strategic control program for $A$. cajennense, as recommended by Labruna et al. (2004) and Cunha et al. (2007). Likewise, other factors may be interfering with the efficiency of tick control, such as the concentration of acaricide emulsion and application method. According to Labruna (2000), in order to improve acaricide baths, these must be performed using at least four or five liters of acaricide emulsion per adult horse, following the manufacturers' label recommendations. However, field observations have demonstrated that many owners have treated their horses with lower volumes than recommended.

Amblyomma cajennense has been implicated as the main vector for $R$. rickettsii, the etiological agent for Brazilian spotted fever, in different regions of the country (LEMOS et al., 1997; GUEDES et al., 2005). Therefore, by studying factors associated with occurrence and distribution of $A$. cajennense on horses in the two microregions of the present study, knowledge of the epidemiological aspects of tick infestation among these animals may be increased. This may assist in implementing strategic control programs in these regions. Efficient control over this arthropod is fundamental for preventing transmission of pathogens with public health significance. Thus, the results presented in this study suggest that unsatisfactory zootechnical and sanitary management, use of an extensive rearing system, rearing done in a low-altitude region and inappropriate use of chemical acaricides are factors that favor occurrences of $A$. cajennense at different levels of infestation among horses in the municipalities studied. 


\section{Acknowledgements}

The authors would like to thank the owners of the farms visited, who kindly made their horses available for this study. This research was supported by grants from the National Council for Scientific and Technological Development (CNPq) of Brazil and the Carlos Chagas Filho Research Support Foundation of the State of Rio de Janeiro (FAPERJ). We also thank the Coordination Office for Improvement of Higher Education Personnel (CAPES). Also grateful the statistical assistance provided by Professor Wagner Tassinari (Mathematics Department at Universidade Federal Rural do Rio de Janeiro).

\section{References}

Aragão H, Fonseca F. Notas de Ixodologia. VIII. Lista e chave para os representantes da fauna ixodológica brasileira. Mem Inst Oswaldo Cruz 1961; 59(2): 115-129. PMid:13861962. http://dx.doi. org/10.1590/S0074-02761961000200001

Barros-Battesti DM, Arzua M, Bechara GH. Carrapatos de Importância Médico-Veterinária da Regiāo Neotropical: Um guia ilustrado para identificação de espécies. São Paulo: Vox/ICTTD-3/Butantan; 2006.

Bittencourt VRE, Massard CL, Grisi L. Atividade in vitro de alguns piretróides sintéticos no carrapato Amblyomma cajennense (Fabricius, 1787). Pesq Agropec Bras 1989; 24: 1193-1199.

Chacón SC, Correia PG, Barbieri FS, Daemon E, Faccini JLH. Efeito de três temperaturas constantes sobre a fase não parasitária de Amblyomma cajennense (Fabricius, 1787) (Acari: Ixodidae). Rev Bras Parasitol Vet 2003; 12(1): 13-20.

Cooley RA, Kohls GM. The genus Amblyomma (Ixodidae) in the United States. J Parasitol 1944; 30(2): 77-111. http://dx.doi. org/10.2307/3272571

Cunha AP, Bello ACPP, Leite RC, Bastianetto E, Ribeiro ACCL, Freitas CMV, et al. Controle estratégico de Amblyomma cajennense (Fabricius, 1787)(Acari: Ixodidae) em eqüinos, Minas Gerais, Brasil - parte I. Rev Bras Parasitol Vet 2007; 16(4): 221-228. PMid:18373899.

Daemon E, Ishizuka AC. Efeito de diferentes temperaturas sobre a ecdise larval de Amblyomma cajennense (Fabricius, 1787) (Acari: Ixodidae). Rev Bras Parasitol Vet 1992; 1(2): 105-107.

Dias E, Martins AV. Spotted fever in Brazil: a summary. Am J Trop Med Hyg 1939; 19(2): 103-108.

Estrada-Peña A, Guglielmone AA, Mangold AJ. The distribution and ecological 'preferences' of the tick Amblyomma cajennense (Acari: Ixodidae), an ectoparasite of humans and other mammals in the Americas. Ann Trop Med Parasitol 2004; 98 (3):283-292. PMid:15119974. http:// dx.doi.org/10.1179/000349804225003316

Guedes E, Leite RC, Prata MCA, Pacheco RC, Walker DH, Labruna MB. Detection of Rickettsia rickettsii in the tick Amblyomma cajennense in a new Brazilian spotted fever-endemic area in the state of Minas Gerais. Mem Inst Oswaldo Cruz 2005; 100(8): 841-845. PMid:16444414. http:// dx.doi.org/10.1590/S0074-02762005000800004

Guglielmone AA, Beati LD, Barros-Battesti M, Labruna MB, Nava $S$, Venzal JM, et al. Ticks (Ixodidae) on humans in South America. Exp Appl Acarol 2006; 40(2): 83-100. PMid:17103085. http://dx.doi. org/10.1007/s10493-006-9027-0
Heuchert CMS, Giulli V Jr, Athaide DF, Böse R, Friedhoff KT. Seroepidemiologic studies on Babesia equi and Babesia caballi infections in Brazil. Vet Parasitol 1999; 85(1): 1-11. http://dx.doi.org/10.1016/ S0304-4017(99)00108-9

Labruna MB, Kasai N, Ferreira F, Faccini JLH, Gennari SM. Seasonal dynamics of ticks (Acari: Ixodidae) on horses in the state of São Paulo, Brazil. Vet Parasitol 2002; 105(1): 65-77. http://dx.doi.org/10.1016/ S0304-4017(01)00649-5

Labruna MB, Kerber CE, Ferreira F, Faccini JLH, De Waal DT, Gennari SM. Risk factors to tick infestations and their occurrence on horses in the State of São Paulo, Brazil. Vet Parasitol 2001; 97(1): 1-14. http:// dx.doi.org/10.1016/S0304-4017(01)00387-9

Labruna MB, Leite RC, Gobesso AAO, Gennari SM, Kasai N. Controle estratégico do carrapato Amblyomma cajennense em eqüinos. Cienc Rural 2004; 34(1): 195-200. http://dx.doi.org/10.1590/S010384782004000100030

Labruna MB. Aspectos da biologia e epidemiologia dos carrapatos de eqüinos no Estado de São Paulo [Tese]. São Paulo: Universidade de São Paulo; 2000.

Lemos ERS, Machado RD, Coura JR, Guimarães MA, Serra-Freire GNM, Amorim M, et al. Epidemiological aspects of the Brazilian spotted fever: seasonal activity of ticks collected in an endemic area in Sáo Paulo, Brazil. Rev Soc Bras Med Trop 1997; 30(3): 181-185. PMid:9197151. http://dx.doi.org/10.1590/S0037-86821997000300002

Lopes CML, Leite RC, Labruna MB, Oliveira PR, Borges LMF, Rodrigues $\mathrm{ZB}$, et al. Host specificity of Amblyomma cajennense (Fabricius, 1787) (Acari: Ixodidae) with comments on the drop-off rhythm. Mem Inst Oswaldo Cruz 1998; 93(3): 347-351. PMid:9698869. http://dx.doi. org/10.1590/S0074-02761998000300014

Massard CA. Ehrlichia bovis (Donatien; Lestoquard, 1936) Diagnóstico, cultivo "in vitro" e aspectos epidemiológicos em bovinos no Brasil [Tese]. Rio de Janeiro: Universidade Federal Rural do Rio de Janeiro; 1984.

Moliterno FM. Febre maculosa brasileira: aspectos epidemiológicos, clínicos e laboratoriais dos casos ocorridos no estado do Rio de Janeiro no período de janeiro de 2004 a dezembro de 2008 [Dissertaçáo]. Rio de Janeiro: Fundação Oswaldo Cruz; 2009.

Oliveira PR, Borges LMF, Lopes CML, Leite RC. Population dynamics of the free-living stages of Amblyomma cajennense (Fabricius, 1787) (Acari: Ixodidae) on pastures of Pedro Leopoldo, Minas Gerais State, Brazil. Vet Parasitol 2000; 92(4): 295-301. http://dx.doi.org/10.1016/ S0304-4017(00)00322-8

Oliveira PR, Borges LMF, Leite RC, Freitas CMV. Seasonal dynamics of the Cayenne tick, Amblyomma cajennense on horses in Brazil. Med Vet Entomol 2003; 17(4): 412-416. PMid:14651655. http://dx.doi. org/10.1111/j.1365-2915.2003.00459.x

Oliveira PR. Biologia e controle de Amblyomma cajennense. Rev Bras Parasitol Vet 2004; 13(s1): 118-122.

Parola P, Raoult D. Ticks and Tickborne Bacterial Diseases in Humans: An Emerging Infectious Threat. Clin Infect 2001; 32(6): 897-928. PMid:11247714. http://dx.doi.org/10.1086/319347

Perez CA, Almeida AF, Almeida A, Carvalho VHB, Balestrin DC, Guimarães MS, et al. Carrapatos do gênero Amblyomma (Acari: Ixodidae) e suas relaçôes com os hospedeiros em área endêmica para febre maculosa no estado de Sáo Paulo. Rev Bras Parasitol Vet 2008; 17(4): 210-217. Pmid:19265580. 
Pinheiro VRE. Avaliação do efeito carrapaticida de alguns piretróides sintéticos sobre o carrapato Amblyomma cajennense (Fabricius, 1787) (Acari: Ixodidae) [Dissertação]. Rio de Janeiro: Universidade Federal Rural do Rio de Janeiro; 1987

Prata MCA, Alonso LS, Sanavria A. Parâmetros biológicos do estádio ninfal de Amblyomma cajennense (Fabricius, 1787) (Acari: Ixodidae) em coelhos. Rev Bras Cienc Vet 1996; 3(2): 55-57.

R Development Core Team. R: A language and environment for statistical computing. R Fundation for Statistical Computing, Vienna, Austria. 2010. [cited 2010 Jan. 31]. Available from: http://www.Rprojetc.org.

Rozental T, Bustamante MC, Amorim M, Serra-Freire NM, Lemos ERS. Evidence of spotted fever group Rickettsiae in State of Rio de Janeiro, Brazil. Rev Inst Med Trop S Paulo 2002; 44(3): 155-158. PMid:12163909. http://dx.doi.org/10.1590/S0036-46652002000300008

Sampaio IBM. Estatística aplicada à experimentaçâo animal. 2. ed. Belo Horizonte: FEPMVZ; 2002.

Serra-Freire NM, Cunha DW. Amblyomma cajennense: comportamento de ninfas e adultos como parasitos de bovinos. Rev Bras Med Vet 1987; 9(5): 100-103
Serra-Freire NM. Epidemiologia de Amblyomma cajennense: Ocorrência estacional e comportamento dos estágios não parasitários em pastagens do Estado do Rio de Janeiro. Arq Univ Fed Rural Rio de Janeiro 1982; 5(2): 187-193.

Souza AP, Serra-Freire NM. Variaçáo sazonal dos estádios adultos de Amblyomma cajennense e Anocentor nitens, como parasitas de cavalos, no município de Itaguaí, RJ, Brasil. Rev Bras Parasitol Vet 1992; 1(1): 31-34.

Souza AP, Serra-Freire NM. Variação sazonal da fase não parasitária de Amblyomma cajennense e Anocentor nitens no município de Itaguaí, RJ: Avaliação epidemiológica e metodológica. Rev Univ Rural: Série Cienc vida, 1994; 16(1-2): 67-74.

Teglas M, Matern E, Lein S, Foley P, Mahan SM, Foley J. Ticks an tick-borne disease in Guatemalan cattle and horses. Vet Parasitol 2005; 131(1-2): 119-127. PMid:15936147. http://dx.doi. org/10.1016/j.vetpar.2005.04.033

Vieira AML, Souza CE, Labruna MB, Mayo RC, Souza SSL, CamargoNeves VLF. Manual de vigilância acarológica. São Paulo: Secretaria Estadual de Saúde do Estado de São Paulo, Superintendência de Controle de Endemias (SUCEN); 2002. 60 p. 